\section{Intensive use of groundwater: challenges \& opportunities}

\author{
Editors: R Llamas \& E Custodio \\ Workshop on Intensively \\ Exploited Aquifers, Madrid, \\ Spain, 13-15 December 2001
}

Balkema Publishers, Netherlands. ISBN 9058093905,498 pages

This book originates from a workshop on intensively exploited aquifers held in Madrid, Spain from 13-15 December 2001. Sponsors of the meeting included: Regional Government of Valencia, Spanish Ministry of Science \& Technology, Marcelino Boti Foundation, International Association of Hydrogeologists, International Water Resources Association, UNESCO's International Hydrological Programme, Food and Agriculture Organisation, International Atomic Energy Agency and the National Ground Water Association. Draft papers by invited authors were discussed by workshop attendees and final papers are presented in this book. This process of deriving papers has produced a more organised final product than most books from workshops and conferences.

The stated main objective of the publication is to examine the pros and cons of intensive groundwater development and 'contribute towards a more objective view of the role that groundwater should play in water resources policy' (page XI). This review summarises the contents of the book and assesses the success of the book in meeting its main objective.

Chapters are arranged in five sections: general considerations; technical issues; socio-economic issues; regional and rational issues; and common issues and the way forward. An impressive review of the use and state of the Earth's groundwater resource is assembled in these chapters. The editors provide various definitions of intensive use of groundwater: 'when the natural functioning of aquifers is substantially modified by groundwater abstraction' (page 3), 'groundwater development that has a significant impact on the hydrological cycle' (page 10) and when 'a significant proportion of the interannual renewable resource is withdrawn from aquifers, which in turn, noticeably modifies their hydrological functioning, or causes significant ecological, political or socio-economic impacts, or important changes are produced to river-aquifer relationships' (page 457). Impacts on the hydrological cycle of large groundwater pumpage include affects on spring and river base-flow, water table depth, piezometric levels, groundwater storage, groundwater-depen-

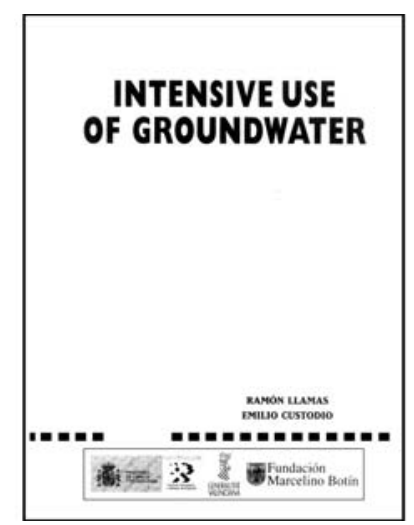

dant wetlands, groundwater quality, riveraquifer relations and land subsidence.

Eight themes of groundwater use are discussed in the section on technical issues: megacities, irrigation, environmental effects, groundwater quality, coastal zones, conjunctive use, drought and economic benefits of intensive use. A strength of this section is the large number of case examples presented. A weakness of the section is that the reader is generally not left with a clear picture of whether the aquifer is 'intensively' used. For example, one gets the impression that pumpage of the Llobregat aquifer (Spain) during drought until the aquifer is almost empty (Chapter 8) does substantially modify the natural functioning of the aquifer but no proof is given. The chapters on 'Environmental implication of intensive groundwater use' and 'intensive groundwater development in coastal zones' have good examples of some of the negative environmental effects. For example a decrease in the length of perennial streams in Kansas and alteration of fish communities are associated with declines in groundwater level in the High Plains aquifer.

Five chapters discuss socio-economic issues of intense groundwater use and cover topics such as economics, property rights, management and education. The complexity of dealing with this complex resource is well illustrated by the many kinds of management regimes that co-exist in the US (Chapter 13).

Six chapters on regional and national issues discuss groundwater in North America, India, China, Japan, Middle East, North Africa and Spain. These chapters contain good compilations of the use, benefits, and environment effects of groundwater development. I particularly enjoyed Chapter 16 discussing social and economic aspects of groundwater in India. Somewhere in the range of $70-80 \%$ of irrigation for agricultural production in India comes from groundwater. Groundwater use has increased over the last 40 years and it is estimated that there were 19 million mechanised wells and tube wells in 2000 . It is predicted that $30 \%$ of the areas using groundwater will face serious problems of over-exploitation by 2017-2018 if the current rate of growth in groundwater use continues. The 'rise and fall' of local economies dependent on groundwater are summarised as a four stage process: the rise of the green revolution; groundwater-based agrarian boom; early symptoms of groundwater overdraft; and decline of the groundwater socio-ecology. The social characteristics and policy interventions typical of each stage provide a fascinating insight to the human-resource dynamic.

The section 'Common issues and the way forward', contains two chapters. The first paper explores the connections between groundwater and poverty and finds that groundwater development rates and declines in poverty between 1956 and 1991 are closely correlated in India. In the last chapter of the book the editors summarise common concepts and suggestions for the way forward.

Also included are an author index, a list of acronyms and a subject index. The smallest geographic entities in the subject index are nations and states (US). Inclusion of cities and regions in the subject index would have improved access to information.

Does the book obtain its main objective? I believe it does. The benefits of groundwater use are outlined and described in good detail. Particularly, the examples of social and economic impacts of groundwater are a welcome contribution to the literature. Negative aspects of groundwater development are also described in good detail and the compilation of environmental problems contains up-to-date research results. The examples of the social and economic benefits of groundwater use, where that use could be described as unsustainable, are very interesting. The chapters covering property rights, law and management are good compilations of the experience of users and regulators around the world. 'Intensive Use of Groundwater' is, therefore, a very useful book for students and professionals.

Intensive groundwater use is a term for which various definitions are provided, and it is not always clear whether groundwater in the examples is used 'intensively' according to the definitions. However, there is no doubt that groundwater use is significant in most of the examples presented.

Is the concept of 'intensive' groundwater use helpful? Perhaps it is, purely as a description of the degree of groundwater use, however the term requires better definition than is offered by the authors in my opinion. It is a less helpful concept when used to describe the aims or effects of groundwater management but certainly intensive use is, in the editors' words (page 459), 'a useful stage towards maturity, following a path that tends to sustainable development'.

\section{P.A. White}

Institute of Geological and Nuclear Sciences Private Bag 2000

Taupo

NEW ZEALAND 